\title{
LABOR ABSORPTION, INFLATION VOLATILITY, AND INFLATION TARGETING FRAMEWORK (ITF): The Case of Three Economic Sectors in Indonesia
}

\author{
Ruth Meilianna \\ Research Center for Population \\ Indonesian Institute of Sciences, Jakarta, Indonesia \\ Email: ruthmeilianna56@gmail.com
}

\begin{abstract}
Labor is one of the important inputs affecting shocks in economy. Various economic problems increase when unemployment is high. High volatility (uncertainty) at prices (this study used inflation), is a risk for the company. When facing the uncertainty, the company can choose to delay investing and change the decisions in recruitment plan; it is used to collect the information about prices before investing (this concept called Irreversible Investment), subsequently cause a reduction in labor absorption. Moreover, this uncertainty is a cost for the company. This condition makes it difficult for companies to determine the optimal number and combination of inputs (including labor), as consequences the company has to decide reducing the inputs. Inflation Targeting Framework (ITF) is one of the frameworks used by Bank Indonesia and the government to reduce and stabilize inflation. There are pros and cons of the irreversible investment concept and the success of the ITF. This study aims to determine whether uncertainty in inflation (illustrated by inflation volatility) affects investment and labor absorption. In addition, it is to find out whether the ITF has succeeded in making inflation stable and affecting other macroeconomic variables. The data used are annual data from volatility of inflation, employment, investment, GDP and ITF dummy. This study used three sectors in Indonesia, for instance, the industrial; trade, restaurants, accommodation services and transportation sector; and transportation, warehousing and communication, because of limited data. The result of this study was that volatility affect the labor absorption, both directly and indirectly (through investment). Furthermore, the ITF has affected the volatility of inflation.
\end{abstract}

Keywords: Inflation, Labor, Volatility

\section{Abstrak}

Tenaga kerja merupakan salah satu input penting yang dapat mempengaruhi naik turunya sebuah perekonomian. Masalah muncul ketika penganguran tinggi. Ketidakpastian yang tinggi pada harga (dalam penelitian ini inflasi), merupakan risiko bagi perusahaan. Ketika diperhadapkan dengan ketidakpastian, perusahaan dapat memilih untuk menunda berinvestasi dan merubah keputusan dalam rencana perekrutan; hal tersebut digunakan untuk mengumpulkan informasi tentang harga sebelum melakukan investasi (konsep ini dinamakan Irreversible investment), pada akhirnya hal ini berpengaruh terhadap pengurangan penyerapan tenaga kerja atau peningkatan penganguran. Ketidakpastian merupakan biaya bagi perusahaan. Kondisi tersebut membuat perusahaan sulit untuk 
menentukan jumlah dan kombinasi input (termasuk tenaga kerja) yang optimal, sehingga perusahaan memutuskan untuk mengurangi input. Inflation Targeting Framework (ITF) merupakan salah satu kerangka kerja yang digunakan oleh Bank Indonesia dan pemerintah untuk menurunkan dan menstabilkan inflasi. Terdapat pro kontra atas konsep irreversible investment maupun keberhasilan ITF. Penelitian ini bertujuan untuk mengetahui apakah ketidakpastian pada inflasi (digambarkan dengan volatilitas inflasi) mempengaruhi investasi dan penyerapan tenaga kerja. Selain itu untuk mengetahui mengetahui apakah ITF berhasil membuat inflasi stabil dan mempengaruhi variabel makroekonomi lainnya. Data yang digunakan adalah data tahunan dari volatilitas inflasi, penyerapan tenaga kerja, investasi, PDB dan dummy ITF. Elastisitas penyerapan tenaga kerja digunakan untuk mengukur penyerapan tenaga kerja. Penelitian ini menggunakan tiga sektor di Indonesia yaitu, sektor industri; perdagangan, rumah makan, jasa akomodasi dan sektor transportasi; dan transportasi, pergudangan dan komunikasi karena adanya keterbatasan data. Hasil dari penelitian ini adalah volatilitas berpengaruh terhadap penyerapan tenaga kerja, baik secara langsung maupun tidak langsung (melalui investasi). Selan itu, ITF mempengaruhi volatilitas inflasi.

Kata kunci: Inflasi, Tenaga Kerja, Volatilitas

\section{INTRODUCTION}

Labor is an important variable that determines the economy of a country and a significant input in the production life of a country as well. An increase or decrease in the economy can be influenced by how much labor is absorbed in an economy. Economy can reach potential output when many workers are absorbed. In other words the input is maximized to achieve maximum output; when all inputs are maximized, in full employment conditions, the economy can achieve potential output (output in optimal conditions); hence the output gap (the difference between actual output and potential output) is smaller in an economy, and the economy increases. Problems arise when unemployment is high and little labor is used in the economy of a country.

Labor conditions in Indonesia can be seen from the amount of unemployment. Indonesia's unemployment rate in 2017 was $5.5 \%$, decreace from the previous year of $5.61 \%$, and relatively low compared to previous years (Figure I). Despite decrease, Song \& Tang (20I6) stated that Indonesia had the highest youth unemployment rate for the I5-24-year age group as compared to Malaysia, Singapore, Thailand and the Philippines, that is, I8.3\%. A large of unemployment rate indicates small workforce that has been optimize in achieving maximum output (potential output) in an economy.

Moreover, the condition of labor can also be seen from the labor absorption. Labor absorption is the amount of labor used in a business unit. Value of labor absorption in the industrial sector; trade, restaurants, accommodation services and transportation sector; and transportation, warehousing and communication are quite volatile (Figure 2).

Labor absorption is influenced by various factors, and one of them is the volatility of inflation. The greater the volatility, the greater the uncertainty of a value. Volatility can be described by standard deviation, by measuring the movements of market price changes. Standard deviation can be used to measure fluctuations in average price movements between a price level. The smaller the level from the average distance, the lower the standard deviation and volatility. The value and movement of inflation is different from inflation volatility (Figure 3 and Figure 4).

The relationship between inflation volatility and labor absorption can be explained through the irreversible investment theory. Irreversible investment can explain the effect of inflation volatility on employment. Volatility is often used to measure stability; the greater the volatility of a value indicates the more unstable the value is. Rother (2004) states that the negative consequences of inflation volatility are specific problems that need to be noticed. High variability of inflation over time makes expectations of future prices more uncertain.

There are several previous studies that examined the effect of inflation on labor absorption, but there is no research that adresses the volatility of inflation to labor absorption. 
Figure I. Indonesia's Unemployment Rate

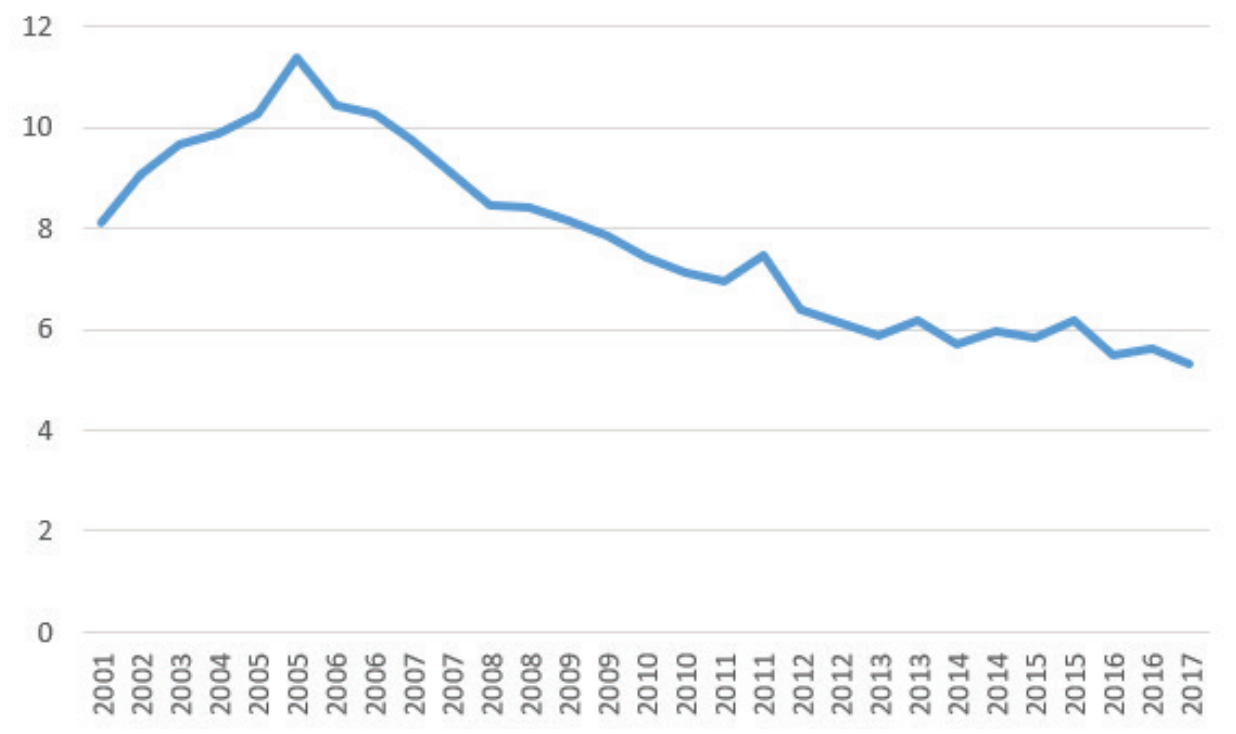

Source: Statistics Indonesia (2018)

Figure 2. Indonesia's Labor Absorption

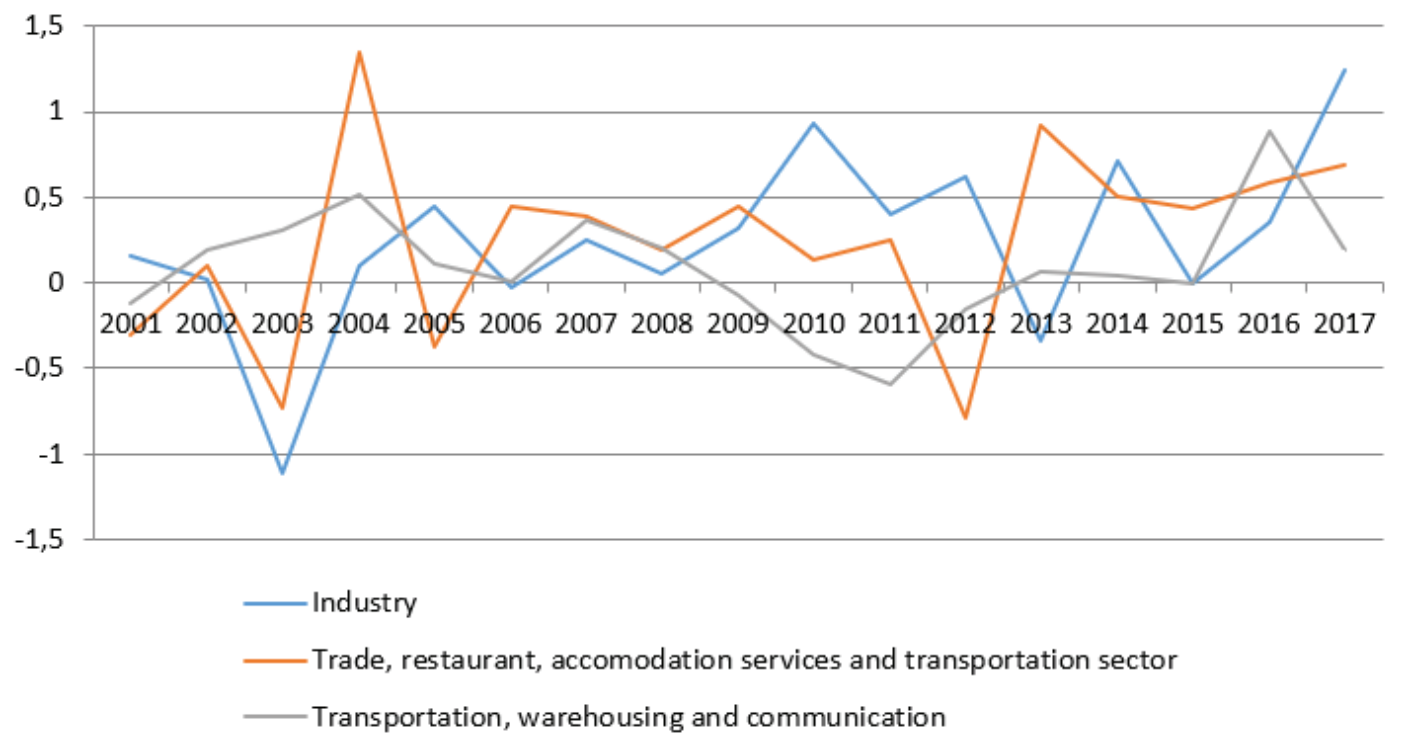

Source: Data processed from Badan Pusat Statistik (2018)

We need to know things that affect employment. By knowing whether inflation volatility affects labor absoprtion or not, we can find out whether further policy is needed to influence inflation volatility. Both of these make the writer interested in writing this paper

Bank Indonesia and the Government collaborate to set inflation and inflation volatility.
One of the frameworks made by Bank Indonesia to set inflation and its volatility is the Inflation Targeting Framework (ITF). In 2005, Indonesia adopted the Inflation Targeting Framework, by announcing the inflation target to the public. Research that discusses the success of ITF on unemployment has been carried out by Divino (2009), Epstein (2007), Francisco et al. 
(2008), and Omojolai (2010), but there are still limited studies that discuss the success of ITF in influencing inflation volatility in Indonesia and its impact on labor absorption, this is also the reason for writing this article.

Based on the background, this study aims to examine the effect of inflation volatility on investment and labor absorption; both directly and through investment or indirect. Second, this study wants to find out whether the ITF, as a framework for making low and stable inflation, has succeeded in influencing inflation stability, and moreover influencing other mareconomy variable.

\section{LITERATURE REVIEW}

\section{Inflation Volatility Affects Labor Absorption}

The inflation value is different from the volatility of inflation. Value of Inflation volatility is different from the inflation value and has a different effect than just inflation, so the effect of inflation volatility is very necessary and important to know. Indonesia's inflation was quite fluctuating from 200I-2017. Inflation was relatively high in 2005, 2006 and 2008, but quite stable after 2009 (Figure 3). In contrast with inflation, inflation volatility has different values, volatility can explain uncertainty or risk in market values changing (Figure 4).
The effect of inflation can also be different from the volatility of inflation. Volatility can describe uncertainty or risk in changing market values. The greater the volatility, the greater the fluctuations that occur, thus the more uncertain the value. Volatility can be described by standard deviation, by measuring the movements of market changes. Standard deviation can be used to measure fluctuations in average price movements between a price level. The smaller the level of the average value, the lower the standard deviation and volatility.

Volatility is often used to measure stability; the greater the volatility of a value indicates the more unstable the value is. Rother (2004) stated that the negative consequences of inflation volatility are specific problems that need to be noticed. High variability of inflation over time makes expectations of future prices more uncertain. This creates risks for the long term; increasing the cost of hedging against inflation risk and creating uncertainty on wealth redistribution (Rother, 2004). Choi \& Loungani (2015), Bernanke (I983), Dixit and Pyndick (1994), stated that uncertainty is a risk for companies, so companies prefer to delay or prefer to reduce their investment, and change their recruitment plans. Futhermore, Bloom (2009) stated that shock at uncertainty has a clear theoretical effect on the evolution of the unemployment rate with the cost of adjusting

Figure 3. Inflation of Indonesia

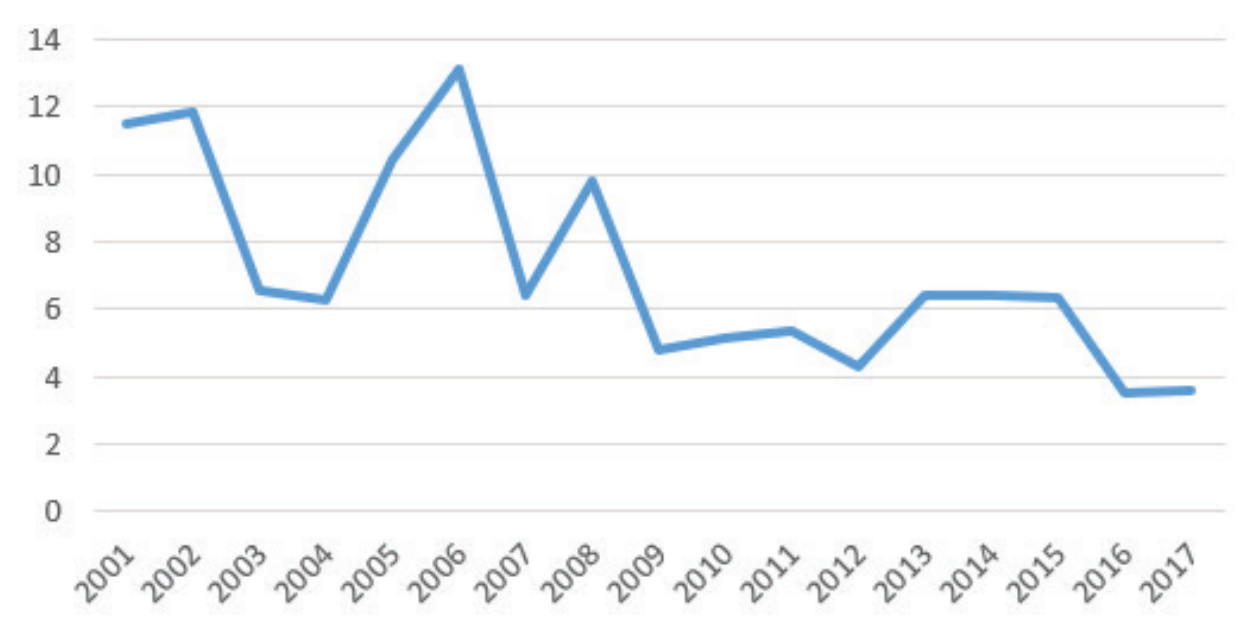

Source: Bank Indonesia' Website (2018) (Bank Indonesia, 20I8) 
Figure 4. Indonesia's Monthly Inflation volatility

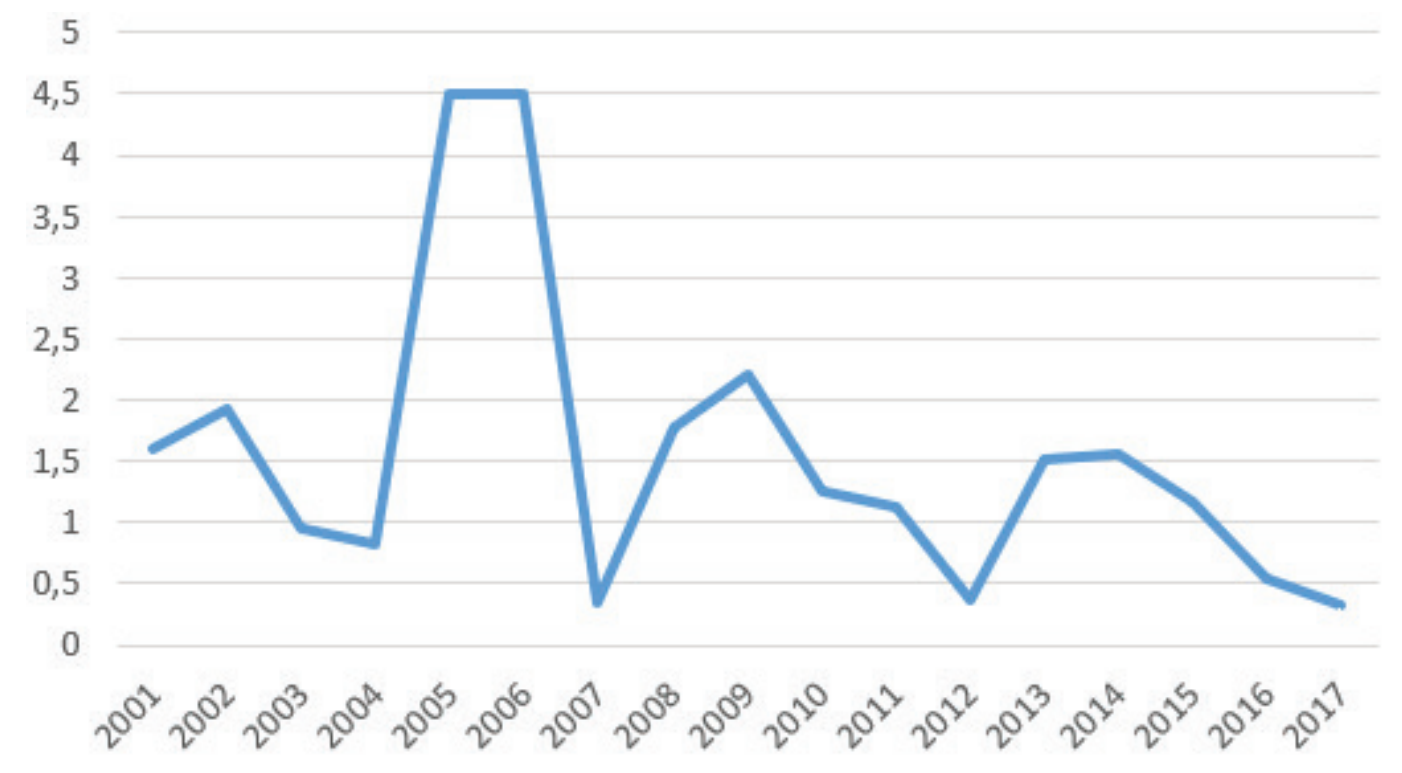

Source: OECD, data processed

labor; waiting value options increase when uncertainty increases, which causes companies to be more careful in making hiring and firing decisions. Choi and Loungani (2015) stated that in economic theory, uncertainty can affect high unemployment through various mechanisms.

Irreversible investment (delaying investing) is done to gather information about prices and other market conditions before making an investment decision. Increasing uncertainty in prices makes companies reluctant to invest and prefers to delay or reduce investment. Inflation volatility can affect employment directly or through investment variables (indirectly). Inflation volatility makes investment decrease (Dixit and Pyndick, I994); and labor inputs used must be decline (Bloom, 2009) (will be explained in the next paragraph).

Uncertainty arising from inflation volatility affects the company's plans to reduce investment or delay investment, and recruit workers. Errais \& Bahri (20I6) stated that investment decisions are usually based on two components of investment, namely risk and profit. Rother (2004) stated that the negative impact of inflation volatility is a problem that needs attention. The high volatility of inflation makes future price expectations more uncertain, which in turn raises risks, which also increases the cost of hedging against inflation risks and raises unexpected redistribution of wealth. Choi \& Loungani (2015), Bernanke (I983), Dixit \& Pindyck (I994) stated that uncertainty is a cost for the company. These costs drive companies prefer to delay investment or prefer to reduce their investment, and which ultimately affects the recruitment plan. Shock in uncertainty has a clear theoretical effect on the evolution of the unemployment rate with the cost of adjusting labor (Bloom, 2009). According to the mechanism, the desire to wait increases when uncertainty increases, causing companies to be more careful in hiring and firing decisions. Choi \& Loungani (2015) and Bloom (2009), found that with uncertainty in stock prices affecting unemployment.

According to Pindyck (I99I), irreversible investment is sunk costs that cannot be recovered. According to him, delaying is possible to gather information about prices and other market conditions before making an investment decision. Nevertheless, Choi \& Loungani (2015) stated that in economic theory, uncertainty can affect high unemployment through a variety of mechanisms. 
Bank Indonesia (2013) stated that inflation stability is a prerequisite for sustainable economic growth. Unstable inflation will create uncertainty for economic actors in making decisions. Empirical experience shows that unstable inflation will make it difficult for the community to carry out consumption, investment and production, which in turn will reduce economic growth (Bank Indonesia, 20I3). Moreover, Dasilva-Filho (2007) found that inflation uncertainty affected company investment in Brazil by increasing the cost of capital and making investment credit relatively rare. The decline in inflation pressure stimulates investment by reducing premium risk, as a low factor price, which makes it easier for companies to finance investment projects.

Fischer (2013) examined the relationship between uncertainty and investment. Using panel data, he found an increase in inflation uncertainty is associated with a reduction in total investment. Moreover, Modigliani (I978) stated that uncertainty about prices will make it difficult to plan. When faced with uncertainty, the company may reduce or delay a consistent investment; such behavior can be proven by the existence of a real model of firm investment behavior.

Onwe \& Olarenwaju (2014) stated that investment is related to unemployment; without investment, unemployment is high. Investment increases capital accumulation. Inflation has an adverse effect on monetary purchasing power, corporate investment and economic growth. Even so, the destabilizing effect of inflation on economic development has been debated, there are negative and positive ones. Without investment, there will be a low level of economic growth, high unemployment rates, and a general increase in poverty levels which results in a depressed social and political system. Investment increases capital accumulation, employment, income growth, and poverty reduction. This is also reinforced by Bank Indonesia (2013) which states that low investment makes employment opportunities decline.
Inflation volatility has a negative impact on inflation and other macroeconomic variables. If prices change constantly, plans for future consumption become more difficult because real household income becomes more volatile, which in turn can make households decide to delay buying large items, which will have a significant negative effect on their lives. (Becker, 2015). Inflation increases the cost of hedging from inflation risk and raises the anticipated redistribution of wealth. Moreover, there are several studies that discuss that inflation volatility affect macro variables. Elder (2004), used VAR found that avage shock to inflation uncertainty has tended to reduce output growth. Judson \& Orphanides (1999), Friedman's (1997), Froyen \& Waud (I987), dan Al-Marhubi (I998) find evidence that inflation volatility has a negative effect on economic growth.

\section{Inflation Targeting Framework (ITF), Inflation Volatility, Investment, and Labor Absorption}

Bank Indonesia and the Government collaborate to set inflation and inflation volatility. One of the frameworks made by Bank Indonesia to regulate inflation and its volatility is the ITF. The framework is the target that needs to be achieved by Bank Indonesia and the Government, in the form of an inflation target. To achieve this goal, the Government maintain the inflation value with various activities such as maintaining the supply of goods, therefore the price of goods remains stable. At the same time Bank Indonesia also regulated monetary policy with various instruments to achieve the inflation target.

In implementing monetary policy, Bank Indonesia has used a framework called the Inflation Targeting Framework (ITF) since 2005. With this framework, Bank Indonesia explicitly announces the inflation target to the public and monetary policy directed towards achieving the inflation target set by the Government (Bank Indonesia, 20I3). To achieve the inflation target, monetary policy is employed in a forwardlooking manner, meaning that a change in the monetary policy stance is carried out through an evaluation of whether future inflation 
developments are still in line with the planned inflation target. Operationally, the monetary policy stance is reflected in the determination of policy interest rates (BI Rate) which are expected to affect money market interest rates, deposit rates and bank lending rates. This change in interest rates will ultimately affect output and inflation.

To influence interest rates in order to achieve the interest rate target, there are several things to do such as open market operations policies, discount policies, cash reserve policies, tight credit policies and capital boost policies. On the other hand, the Government also cooperates with Bank Indonesia to influence the level of goods prices by regulating the level of supply of goods so that prices of goods remain stable. One example of what the government does to maintain the level of goods prices is the establishment of Tim Pengendalian Inflasi Daerah (TPID) or Regional Inflation Control Team. According to the Instruction of the Minister of Home Affairs (Inmendagri) Number 027/1696/ SJ concerning Safeguarding the Affordability of Goods and Services in the Regions as a guideline for Regions in implementing TPID coordination in maintaining price stability. There are several steps needed by the region in order to maintain economic stability in the region and overcome the economic problems of the real sector and maintain the stability of prices of goods and services, such as maintain and increase the productivity of supply; smooth distribution of agricultural products, especially staple food commodities; encourage the creation competitive, efficient market structure and trade systems, especially for commodities that are the basic needs of the community; manage the impact of adjusting the prices of goods and services determined by the Central and Regional governments, including fuel prices, electricity tariffs, and much more.

Some central banks in other countries use inflation targeting as a response to the failure of other monetary policy regimes (Hammond, 20I2). Commitment to the public that explicitly controls inflation as the main goal of policy, emphasizing transparency and accountability is what makes the ITF different from other monetary frameworks. The key to Canada's success in using the ITF is a strong and increasing commitment to transparency and communication and a monetary policy strategy to the public.

The ITF is not only used to maintain the inflation rate in the target range but also reduce its volatility (stability). The high volatility of inflation has the potential to destroy economic performance (Kumo, 2015) This is reinforced by Fielding (2008) which stated that future price uncertainty can lead to higher risks and unexpected changes in wealth, which in the end can lead to higher economic costs. Although there is a debate on the empirical evidence of the success of the influence of the ITF on inflation and inflation volatility, some economic literature states that the ITF has had great success in reducing inflation and inflation volatility. Kumo (2015) \& Mishkin and Posen (I998) found that ITFs had succeeded in making inflation low and stable in Canada.

Kumo (2015) stated that adopting the ITF reduces not only inflation, but also inflation volatility, then can mitigate the negative effects of inflation uncertainty on economic growth for a decade and a half. Mishkin \& Schimdt-Hebbel (2007), based on empirical evidence, concluding that inflation targeting helps countries achieve lower inflation and inflation variability. Mishkin and Schmidt-Hebbel (2007) found that the ITF helped countries achieve lower inflation rates and lower inflation variability than non-ITF countries. Walsh (2009), found that on average, ITF caused a decrease in inflation in each country inflation targeting groups compared to a group of countries that had not adopted the ITF. Moreover, Walsh (2009), found a decrease in inflation accompanied by a decrease in inflation volatility for each country adopting the ITF, both the standard deviation level and its coefficient of variation (standard deviation divided by the mean). Lin \& Yen (2009) found that inflation targeting in thirteen developing countries that had adopted the ITF significantly reduced inflation and inflation volatility. Emera (20I2), states all of the 28 countries that adopted the ITF could minimize the impact of external shocks much better than countries that did not 
carry out the ITF. Furthermore, Roger (2010) states that when there was a shock to commodity prices in 2006 to 2008 , countries having the same income could have different growth; countries adopting the ITF have a smaller reduction in growth compared to countries that do not adopt the ITF. Inflation targeting in Sout Africa made financial condition stable sompared to when at the rezim South African Reserves Bank (SARB) (Wolassa, 20I5). Moreover, Divino (2009), Epstein (2007), Francisco et al. (2008), Omojolai (20I0), discusses the success of ITF on unemployment.

\section{RESEARCH DATA AND METHODS}

\section{Research Data}

This study employed annual data from volatility in inflation, labor absorption, investment, GDP and ITF dummy. Annual inflation volatility data is obtained from the monthly standard deviation of inflation for a year. The source of inflation data comes from the OECD. Labor absorption is obtained from the elasticity of labor absorption (explained in the annex) obtaining from the following formula:

The data used to measure job opportunity were the data of the population aged I5 years by sector during the past week for the industrial sector, trade sector, restaurants and accommodation services, and the transportation, warehousing and communication sectors for the years 200I-20I7 due to limited datta. The data was taken from Statistics Indonesia. Investment data comes from BKPM. Investment data uses investment data per sector from 200I-20I7. The GDP data used in this study is nominal GDP (current price) data from 200I-20I7 for the three sectors described previously. Source of GDP data is obtained from Statistics Indonesia. To measure the ITF dummy, this study employs ITF dummy data (before and after ITF). Dummy o for before ITF and Dummy I for after ITF. Dummy o for 200I-2004; dummy I for 200520I7, since Indonesia using the ITF in 2005. If the dummy variable affects the dependent variable significantly, means the value of dependent variable is different between before ITF and after ITF. When the result is positive, means the dependent variable increases after ITF and vice versa. If the interaction variable (dummy variable*independent variable) affects the dependent variable, it means the effect of the interaction variable on the dependen variable after ITF is different from the effect of the interaction variable on the dependen variable before the ITF.

\section{Methods}

The method used in this study was vector autoregression because some variables used are macro variables, so they need to be processed systemically.

The following are the equation in this study:

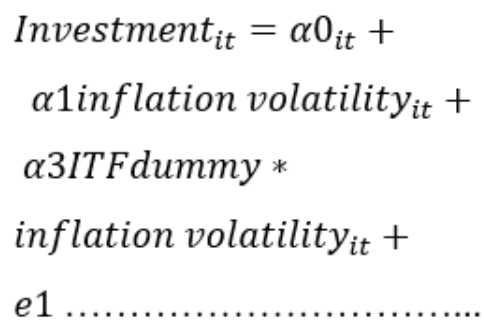

Labor $_{\text {Absorption }}$ it $=\beta 0+$ $\beta 1$ inflation volatility $_{i t}+$ $\beta 2 I T F$ dummy $_{i t}+$ $\beta 3$ ITF dummy ${ }_{i t} *$ inflation volatility $_{i t}+\beta 4 G D P_{i t}+$ ${ }_{\beta}$ investment $_{i t}+$

$e 2$

Inflation volatility $_{i t}=\partial 0+$ d1ITF dummy it +

$\partial 2 G D P_{i t}$

The next thing that needs to be done by the $t$ test statistic is by comparing the t-statistical value with the value of $\mathrm{t}$ table.

The hypothesis in the $t$ test is a follow: Ho: The dependent variable is not significantly 
affected by the dependent variable

Hr: The dependent variable is significantly affected by independent variables.

$\mathrm{T}$ statistic is obtained from the processed VAR data that we have processed while the value of $\mathrm{t}$ table is obtained from table $\mathrm{t}$ (Alpha / 2, n-I). This study applied hypothesis testing with alpha $5 \%$, while the free degree of testing is $n-k$. The partial $t$ test regression curve can make it easier for us to test $\mathrm{t}$ statistics. On the $\mathrm{t}$ test regression curve, we need to determine the area of negative influence, the area of positive influence and the area of no influence, which is determined based on the value of $t$ table (Alpha / 2, n-I). After knowing this we know whether the variable has an effect on other variables.

The following are the result of processed data:

\begin{tabular}{|c|c|c|c|}
\hline No & Influence & $\begin{array}{l}\text { Value of } t \\
\text { test }\end{array}$ & $\begin{array}{l}\mathrm{HO} / \\
\mathrm{H} 1\end{array}$ \\
\hline 1 & $\begin{array}{l}\text { Inflation Volatility }(-1)=>\text { Invest- } \\
\text { ment }\end{array}$ & $-0,55612$ & OK \\
\hline 2 & $\begin{array}{l}\text { Inflation Volatility }(-2)=>\text { Invest- } \\
\text { ment }\end{array}$ & $-0,43117$ & OK \\
\hline 3 & Dummy ITF $(-1)=>$ Investment & $-1,29230$ & OK \\
\hline 4 & Dummy ITF $(-2)=>$ Investment & 0,93308 & OK \\
\hline 5 & $\begin{array}{l}\text { Dummy ITF*Infaltion Volatility }(-1) \\
=>\text { Investment }\end{array}$ & 0.75994 & OK \\
\hline 6 & $\begin{array}{l}\text { Dummy ITF*Infaltion Volatility (-2) } \\
=>\text { Investment }\end{array}$ & 0.33833 & OK \\
\hline 7 & $\begin{array}{l}\text { Inflation Volatility }(-1)=>\text { Labor } \\
\text { Absorption }\end{array}$ & -2.60626 & NO \\
\hline 8 & $\begin{array}{l}\text { InflationVolatility }(-2)=>\text { Labor } \\
\text { Absorption }\end{array}$ & 1.18180 & OK \\
\hline 9 & $\begin{array}{l}\text { Dummy ITF }(-1)=>\text { Labor Absorp- } \\
\text { tion }\end{array}$ & -1.12057 & OK \\
\hline 10 & $\begin{array}{l}\text { Dummy ITF }(-2)=>\text { Labor Absorp- } \\
\text { tion }\end{array}$ & 1.11205 & OK \\
\hline 11 & Dummy ITF*Infaltion Volatility (-1) & 2.55297 & NO \\
\hline 12 & Dummy ITF*Infaltion Volatility (-2) & -1.19300 & OK \\
\hline 13 & $\begin{array}{l}\text { Investment }(-1)=>\text { Labor absorp- } \\
\text { tion }\end{array}$ & -0.17445 & OK \\
\hline 14 & $\begin{array}{l}\text { Investment }(-2)=>\text { Labor absorp- } \\
\text { tion }\end{array}$ & 0.49666 & OK \\
\hline 15 & $\begin{array}{l}\text { Dummy Volatility }(-1)=>\text { Inflation } \\
\text { Volatility }\end{array}$ & $-0,338176$ & OK \\
\hline 16 & $\begin{array}{l}\text { Dummy Volatility }(-2)=>\text { Inflation } \\
\text { Volatility }\end{array}$ & -11.1554 & NO \\
\hline
\end{tabular}

Based on result of processed data there are several conclusions. The result indicates ITF has a negative effect on inflation volatility in lag I, which means that after the ITF, inflation volatility decreases. This indicates that after the ITF policy, inflation volatility changes. Second, inflation volatility affects investment negatively, which means an increase in inflation volatility decreases investment. This is in line with the theory and previous research which stated that the existence of volatility reduces investment. Third, investment affects labor absorption negatively in lag I but is positive in lag 2. This indicates an increase in investment reduces labor absorption in the first year, but in the second year the increase in investment can increase labor absorption. This means that an increase in investment can indeed lead to an increase in labor absorption but only in the second year. In addition, inflation volatility affects labor absorption negatively in lag I. This means that the increase in inflation volatility causes a decrease in labor absorption. Broadly speaking, an increase in inflation volatility causes a decrease in labor absorption directly or indirectly (through investment channels). Another result, after the ITF, inflation volatility declined in lag I but increased in the lag 2. Furthermore, the effect of inflation volatility on labor absorption absorption was different before and after the ITF and the changes declined in the first year. The effect of price volatility on macro variables can vary and can go through many paths and price volatility can be an advantage for certain people, they will take advantage of price changes for profit. As an example, wealthy consumers can buy large quantities of goods when low prices will then store items for sale later (FAO, 2OII).

Related to the result of this study, the recommendation is the ITF and all efforts made to stabilize prices need to be strengthened because the volatility of inflation is proven to affect labor absorption. In addition, according to FAO (20II) there are ways to stabilize prices in the short term, namely with trade policy and buffer stock. In addition, improving the market information system can also be done to reduce price volatility as well. The last is with a food security strategy that is more effective in enhancing food security than a strategy that relies primarily on the closure of borders. 


\section{CONCLUSION}

The result of this study indicates, first inflation volatility decreases after the ITF policy in Indonesia. Moreover, the inflation volatility affects the labor absorption, both directly and indirectly (through investment); a reduction in inflation volatility increases employment. The results of this study are still in line with existing theories. In relation to recommendations, there are several things that can be done besides strengthening the efforts made to achieve ITF such as the TPID, namely trade policy and buffer stock, improving the market information system, and food security strategy. The problem of price volatility is a complex problem, it can even influence through many channels. Special attention is needed to the issue of price volatility by means of more writing and research related to the problems and solutions to the problem, therefore more solutions are found that can reduce the risk of price volatility. There is a weakness in this study, because of the limited data, this study only employs 3 economic sectors. It is hoped that there will be more writings that can complement the weaknesses of this paper.

\section{REFERENCES}

Al-Marhubi, F. (1998). Cross-country evidence on the link between inflation volatility and growth. Applied Economics, 30, pp. 1317-I326.

Badan Pusat Statistik. (20I8). Retrieved from Tenaga Kerja: https://www.bps.go.id/subject/6/ tenaga-kerja.html\#subjekViewTab3

Bank Indonesia. (2013). Retrieved from Inflasi: https://www.bi.go.id/id/moneter/inflasi/ pengenalan/Contents/Default.aspx

Bank Indonesia. (20I7). Kegunaan dan dampak inflasi untuk perumusan kebijakan moneter.

Bank Indonesia. (2018). Retrieved from Inflasi: https://www.bi.go.id/id/moneter/inflasi/ data/Default.aspx

Becker, N. I. (2015). Inflation Volatility and Economic Growth: A Disaggregated Analysis. Thesis in Economics in Trinity College of Duke University.

Bernanke, B. N. (I983). Irreversibility, uncertainty, and cyclical investment. Quarterly Journal of Economics, 98(I), 85-106.
Bloom, N. (2009). The impact of uncertainty shocks. Econometrica, 77(3), 623-65.

Caraiani, P. (2006). The relationship between unemploymen and output cycles in Korea. Romanian Journal of Economic Forecasting, I, $5 \mathrm{I}-64$.

Choi, S., \& Loungani, P. (2015). Uncertainty and unemployment: the effects of aggregate and sectoral channels. IMF Working PaperNo $15 / 36$.

Dasilva-Filho, T. N. (2007). Is the investment uncertainty link realy ellusive? The harmful effect of inflation uncertainty in Brazil. Banco Central Bank, Brazil, Working Paper Series, No 157.

Dickey, A. D., Bell, W. R., \& Miller, R. B. (I986). Unit roots in time series models: test and implications. The American Statistician, 40, 12-26.

Divino, A. J. (2009). The impact of inflation targeting of inflation targeting on unemployment in developing and emerging economies. International Policy Centre for Inclusive Growth Working Paper No. 56.

Dixit, A., \& Pindyck, R. (1994). Investment under uncertainty. Princeton: Princeton U. press.

Elder, J. (2004). Another perspective on the effects of inflation uncertainty. Journal of Money Credit and Banking, 36, 9II-28.

Emara, N. (20I2). Inflation volatility, institutions, and economic growth. Global Journal of Emerging Market Economies, 4(I), 29-53.

Epstein. (2007). Central bank, inflation targeting and employment creation. Economic and Labour Market Papers, employment Analysis and Research Unit Economic and Labour Market Analysis Departement.

Errais, E., \& Bahri, D. (2016). Is standar deviation a good measure of volatility? The case of African markets with price limits. Annals of Economics and Finance, I7(I), I45-I65.

Fielding, D. (2008). Inflation volatility and economic development: Evidence from Nigeria. University of Otago, Economic Discussion Papers No. 807.

Fischer, G. (2013). Investment choice and inflation uncertainty. The London School of Economics and Political Science Working Paper.

Food and Agriculture Organization. (20II). The State of Food Security in the World, How Does International Price Volatility Affect Domestic Economies and Food Security.

Francisco, A. R. (2008). Does Inflation Targeting Matter for Output Growth? Policy Research Working Paper, N. 479I. 
Friedman, M. (I977), "Nobel lecture: Inflation and unemployment", Journal of Political Economy, 85 , June, $45 \mathrm{I}-472$

Froyen, R. \& R. Waud (I987), "An examination of aggregate price uncertainty in four countries and some implications for real output", International Economic Review, 28(2), pp. 353-372.

Hammond, G. (2012). State of the art of inflation targeting, Centre for Central Banking Studies Handbook No. 29. London: Bank of England.

Judson, R. \& A. Orphanides (I999), "Inflation, Volatility and Growth", International Finance, 2(I), pp. II7-I38.

Kumo, L. W. (2015). Inflation targeting monetary policy, inflation volatility and economic growth in South Arica. African Developmnet Bank Group Working Paper Series No 216.

Lin, C.-C., \& Ng, S. (20I2). Estimation of panel data models with parameter heterogeneity when group membership is unknown. Journal of Econometric Methods, I(I), 42-55.

Lin, S., \& Ye, H. (2008). Does inflation targeting really make a difference? The other side of the story from developing countries. Ninth Annual Conference of the Central Bank of Chile on Monetary Policy under Inflation Targeting. Santiago, Chile.

Mishkin , F. S., \& Posen , A. S. (I998). Inflation targeting: Lessons from four countries. NBER Working Paper No. 6I26.

Mishkin, F. S., \& Schimdt-Hebbel. (2007). Does inflation targeting make difference. NBER Working Paper No. 12876 .
OECD. (20I8). Retrieved from Inflation (CPI): https://data.oecd.org/price/inflation-cpi.htm

Omojolaib, A. J. (20Io). Output Effects of Inflation Targeting; Empirical Evidence for the Nigerian Economy. International Journal of Economics, 4(2), 373-380.

Onwe, J. O., \& Olarenwaju, R. R. (20I4). Impact of Inflation on Corporate Investment in the Sub-Saharan african countries: an empirical analysis of the west-african monetary zone. (5(8), Ed.) International Journal and Business and Social Science.

Pindyck, R. (I99I). Ireversible, Uncertainty, and Investment. Journal of Economic Literature, 29(3), IIIO-II48.

Pindyck, R. S. (I99I). Irreversibility, uncertainty and investment. Journal of Economic Literature, 29, IIIO-II48.

Rother, C. P. (2004). Fiscal policy and inflation volatility. European Central Bank Working Paper Series No 3I7.

Song, T. K., \& Tang, J. (20I6). Managing Skills Challenges in ASEAN-5. Singapore Management University and J.P. Morgan Report.

Walsh, C. E. (2009). Inflation targeting: What have we learned. International Finance, I2(2), I95-233.

Wollasa, L. Kumo (2015). Inflation Targeting Monetary Policy, Inflation Volatility and Economic Growth in South Africa. Working Paper Series of African Development Bank Group No 216. 


\section{ANNEX 1}

Formula of the elasticity of labor absorption:

$$
\mu N=\frac{L^{0}}{Q^{0}}
$$

Explanation:

$\mu N=$ Elasticity of Labor absorption

$L^{0}=$ Job opportunity growth rate (\%)

$Q^{0}=$ Production value growth rate (GDP growth rate) (\%)

Job opportunity growth rate is measured by a formula:

$L^{0}=\frac{L_{t}-L_{t-1}}{L t-1} \times 100 \%$

Explanation:

$L^{0}=$ Job opportunity growth rate

$L_{t}=$ Value of job opportunity rate in year $\mathrm{t}$

$L t-1=$ Value of job opportunity rate in year t-I

GDP growth rate is measured by the formula

$Q^{0}=\frac{Q_{t}-Q_{t-1}}{Q t-1} \times 100 \%$

Explanation:

$Q^{0}=\mathrm{GDP}$ growth rate

$Q_{t}=$ Value of GDP in year $\mathrm{t}$

$Q t-1=$ Value of GDP in year t-I 